\title{
The Development and Validation of a Local Wisdom-Integrated Physics Module to Grow the Students' Character of Sanggup Bagawi Gasan Masyarakat
}

\author{
Misbah ${ }^{1}$, Maya Hirani ${ }^{2}$, Syubhan Annur ${ }^{3}$, Nurul F Sulaeman ${ }^{4}$, Mohd Ali Ibrahim ${ }^{5}$ \\ Lambung Mangkurat University, Indonesia ${ }^{1,2,3}$, Shizuoka University, Japan ${ }^{4}$, Universiti \\ Teknologi Malaysia, Malaysia ${ }^{5}$ \\ misbah_pfis@ulm.ac.id ${ }^{1}$, hiranimaya@gmail.com² ${ }^{2}$,subhan.science.edu@unlam.ac.id ${ }^{3}$, \\ nurulsulaeman@yahoo.com ${ }^{4}$,p-mali@utm.my ${ }^{5}$
}

Received: September $20^{\text {th }}, 2019$. Revised: November $28^{\text {th }}, 2019$. Accepted: December $2^{\text {nd }}, 2019$

\section{Keywords :}

Physics Module; Local Wisdom;

Sanggup Bagawi Gasan

Masyarakat

\begin{abstract}
This study is aimed to describe the feasibility of a local wisdom-integrated physics module to grow the character of sanggup bagawi gasan masyarakat, that viewed from the aspect of validity, practicality, effectiveness, and the achievement of student's character. This module is integrated to the production of brown sugar in Balangan Regency, as a local activity that related to heat and temperature materials. This research is a research development with ADDIE design. The subjects of this research were 27 students of class $X$ in one of the high schools in Balangan. The research instruments were validation sheets, student response questionnaires, learning achievement test, and character observation sheets. The result shows that physics module has a good aspect of validity, good practicality, moderate effectiveness, and it is very good on training student's character. Physics module which is integrated to the local wisdom to grow the character of sanggup bagawi gasan masyarakat is feasible to use on heat and temperature materials.
\end{abstract}

\section{INTRODUCTION}

One of the goals of learning in schools is to develop student's potential not only the cognitive ability but also the character of student [1]. The development of student's characters is one of the major concerns to be trained in the learning process [2]. The character owned by scientists or those who learn physics determine the benefits of learning outcomes obtained [3]. Local wisdom can be the basis of educational character [4]. The application of a nation local wisdom's values in learning becomes very important so that it can figure the personality that follows the noble values of the nation's culture [5-6].

The quality of learning can be improved through the use of local culture [7]. The use of local knowledge in learning is indeed necessary [8-10]. Teachers need to integrate the concept of physics studied by the students to the culture around the students [11]. In addition, the learning process will be more 
The Development and Validation of a Local Wisdom-Integrated Physics Module... Misbah, Maya Hirani, Syubhan Annur, Nurul F Sulaeman, Mohd Ali Ibrahim

meaningful if there is a relationship between the material being taught and the daily activities around the students [12]. The integration of physics material to the local wisdom will make students easily understand the physical and cultural material of their own region. As students feel it and easily sensed it themselves [13]. Physics learning or local wisdom-based physics is aimed to give good knowledge and character to students [14].

Student character values fail to be taught by the teacher if the character of education has not been carried out systematically in the learning process [15-16]. This is also supported by observations and interviews with physics teachers in one of the state high schools in Balangan Regency; it was found that the character of students has not been optimized in the learning process, student's activity and learning outcomes are also lacking, as well as a teaching material that link physics material to the local wisdom does not yet exist in the school. Therefore, we need teaching materials that can connect the local wisdom and physics material, one of them is a module.

The existence of a local wisdom-integrated physics module is expected to be an alternative to improve the effectiveness of learning process. Local wisdom is the intelligence of the local community gained through the experiences or habits of the community through a long journey [17]. Local wisdom is a set of knowledge, values, behaviours, and the way to behave towards certain objects and events in their environment that the goodness and the truth are accepted. The integration of local wisdom in physics teaching materials will make it easier for students to understand and accept physics lesson [18]. However, the integration of local wisdom to physics module is lacked to conduct. Our research focused on one character in Balangan Regency. The local wisdom referred is the production of brown sugar and the character of sanggup bagawi gasan masyarakat in which as the local wisdom from the area of Balangan Regency. The production of brown sugar are interconnected with the character of sanggup bagawi gasan masyarakat because Francis Wahono [4] states that local knowledge does not stop only on the intelligence and management strategies of the universe, but also on the ethics and norms. So, the ethics and norms referred are the character of sanggup bagawi gasan masyarakat which means cooperation. For this reason, it is very necessary to have a physics module that integrates the production of brown sugar and the character of sanggup bagawi gasan masyarakat to make the learning of physics be more meaningful.

Local wisdom-based learning has been able to develop positive character of students [19-20]. Learning devices which based on local wisdom are effective in improving student's critical thinking skills [21]. Local wisdom-based learning model has an effect on student's creativity and learning outcomes $[20,22]$. This study uses the object or character of local wisdom which is different from the existing studies, that is the integration of brown sugar production to train the character of sanggup bagawi gasan masyarakat on temperature and heat materials. The objective of this study is to describe the feasibility of a local wisdom-integrated physics module to grow the character of sanggup bagawi gasan masyarakat, in terms of aspects of validity, practicality, effectiveness, and the achievement of student's character.

\section{METHOD}

This type of research is research and development. Produced and developed product is in the form of a local wisdom-integrated physics module to grow the character of students on temperature and heat materials. The development model used is ADDIE (Analysis, Design, Development, Implementation, and Evaluation). The analysis stage is analysing the required competence to the students, analysing the characteristics of the students, and analysing the material based on required competence. The design stage is designing physics module that integrate the local wisdom based on what is needed. The local wisdom referred is to relate temperature and heat materials to the process of producting brown sugar in Balangan Regency and the character of sanggup bagawi gasan masyarakat. The development stage is production and development of a local wisdom-integrated physics module. A developed local wisdom-integrated physics module is used to grow the character of sanggup bagawi gasan masyarakat. The local wisdom referred in this study is the process of 
producing brown sugar in Balangan Regency and the society's character of sanggup bagawi gasan masyarakat in Balangan Regency. The material used is temperature and heat which associated with the process of producing brown sugar. The use of this module consists of four meetings, including: 1) heat and change of its form, 2) expansion and heat transfer by conduction, 3) heat transfer by convection and radiation, and 4) the Black principle. The implementation stage is using a module that has been developed in the learning process in one of the classes at SMAN in the city of Balangan. The Evaluation stage is evaluating the feasibility of the developed module viewed from the aspects of validity, practicality, effectiveness, and achievement of student's characters.

The trial subjects were 27 students in one of high schools in Balangan Regency. The research instruments used were validation sheets, questionnaire of student's response, learning achievement test, and character's observation sheet. There were 10 essays questions. Validation was done to know the level of validity of the developed module and then revised based on the suggestions given by the validators. The scores obtained from the validator were then analysed and adjusted to the validation criteria which was adapted from Widoyoko [23]. The module practicality data is reviewed based on the analysis of questionnaire of student's response that covers the aspects of ease of use, benefit, and efficiency of learning time. The scores obtained were then analysed and adjusted to practicality criteria [23]. The effectiveness of learning was measured from the test of learning outcomes by conducting a pre-test and post-test. Learning outcomes tests are given before students use the physics module based on local wisdom (pre-test). implementation of learning for 4 meetings. after students learn to use physics modules based on local wisdom, students are given a test of learning outcomes (post-test). The results obtained were then analysed using the normalized gain (N-gain) equation [24]. Student's character observation sheets were used during the learning process. The average score obtained was adjusted to the criteria of student's achievement towards the character of sanggup bagawi gasan masyarakat.

\section{RESULTS AND DISCUSSIONS}

Cover of a local wisdom-integrated physics module can be seen on Figure 1.

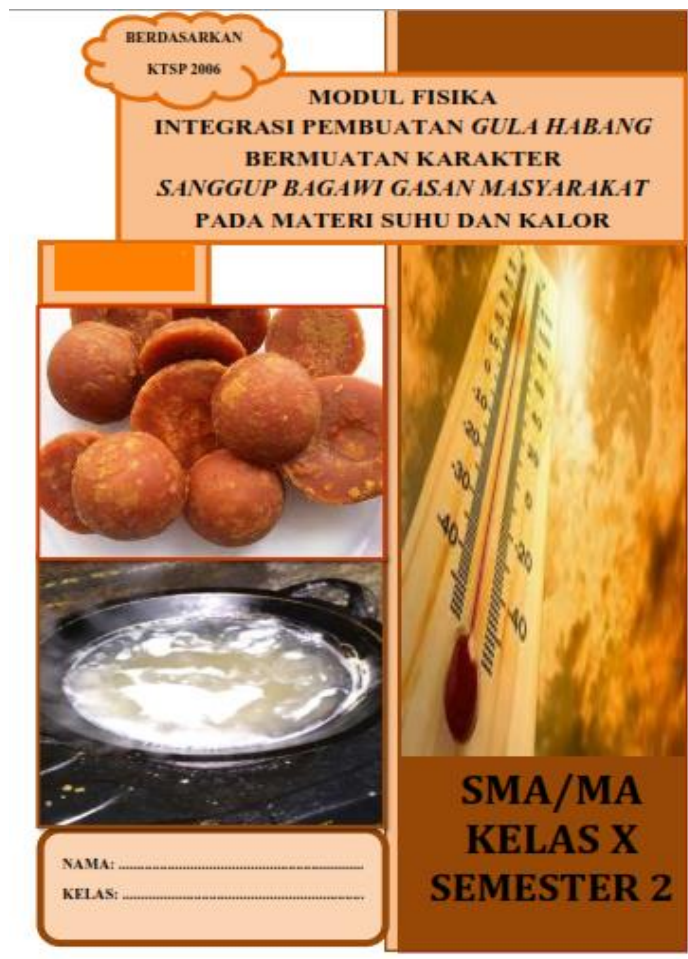

Fig 1. Cover of a Local Wisdom-Integrated Physics Module 
The Development and Validation of a Local Wisdom-Integrated Physics Module... Misbah, Maya Hirani, Syubhan Annur, Nurul F Sulaeman, Mohd Ali Ibrahim

\section{Module Validation Result}

Module validation is obtained using validation sheet from three validators, they are two academicians and a practitioner. The result of module validation content and module layout by the three validators can be seen in Table 1 .

Table 1. Result of Module Material Validation

\begin{tabular}{lcclcc}
\hline \multicolumn{2}{c}{ Module Content Validation Results } & \multicolumn{2}{c}{ Module Display Validation Results } \\
\hline Aspect & Average & Category & Aspect & Average & Category \\
\hline Quality of Content & 3.20 & Good & Consistency & 3.44 & Very good \\
Organization & 3.00 & Good & Format & 3.50 & Very good \\
Language & 3.40 & Good & Attractiveness & 3.25 & Good \\
Evaluation & 3.00 & Good & Font Form and Size & 3.56 & Very good \\
Glossary & 3.00 & Good & Language & 4.00 & Very good \\
Validity & 3.12 & Good & Validity & 3.55 & Very good \\
Reliability & 0.71 & Quite Good & Reliability & 0.76 & Quite Good \\
\hline
\end{tabular}

Table 1 shows that the result of the content of module validation is categorized as good and the validation of the module's layout is categorized as very good. This shows that the physics module that has been developed is appropriate from various aspects in terms of content (quality, organization, language, evaluation, and glossary) and layout (consistency, format, attractiveness, font form and size, and language). This is in accordance with the opinion which states that a good module must meet the content and display aspects that are good [12]. The physics modules that have been declared valid can be used in the testing phase at the school [1]. Furthermore, the physics module that has been validated is then improved based on the suggestions from the three validators in order to obtain a better physics module. So that it can be tested to find out its practicality and effectiveness.

\section{Practicality of Module}

The practicality of student's module is measured based on student's response questionnaire. The following is the result of practicality of module that can be seen in table 2 .

Table 2. The Result of Practicality of Module

\begin{tabular}{lcc}
\hline \multicolumn{1}{c}{ Indicator } & Average & Category \\
\hline Ease of Use & 3.43 & Very Good \\
Benefit & 3.19 & Good \\
Learning Time Efficiency & 3.32 & Good \\
Average & 3.31 & Good \\
\hline
\end{tabular}

Based on Table 2, it is obtained that the practicality of module is categorized as good. This means the module that has been developed is easy to use, beneficial for students, and the learning time is also efficient. This is in accordance with the opinion that which states that a practical module is a developed module that is easy to be implemented, has a relatively short time to develop, and the module contains instructions that can facilitate others to use it [23,25-26]. This is in accordance with the definition of the module itself, that is teaching material written by the teacher to ease students in learning the learning material independently [27], it is arranged using the language that is easily understood by students based on their level of knowledge and age [28].

\section{Module Effectiveness}

The effectiveness of the developed module is measured by using the test of student's learning outcomes, then analysed by using $\mathrm{N}$-Gain. The module effectiveness result is presented in Table 3 . 
Table 3. Module Effectiveness Result

\begin{tabular}{ccc}
\hline Pre-test Average & Post-test Average & N-Gain \\
\hline 6.45 & 64.7 & 0.62 \\
\hline
\end{tabular}

Based on Table 3, it is obtained that the effectiveness of the module with $0.62 \mathrm{~N}$-gain score is in moderate category. These result indicates that student's learning outcome after learning by using a local wisdom-integrated physics module to train the character of sanggup bagawi gasan masyarakat on temperature and heat materials is improved and categorized as moderate category. The developed module is able to achieve the stated learning goals [29] and is effectively used in the learning process [30]. The use of modules is effective if it reaches the expected learning objectives [31].

A local wisdom-integrated physics module presents facts that are close to student's daily activities, this will make student is easy to perceive them. It also improves student's motivation because of the relevance of physics material that they learn with their environment. The description of material and example presented in module are relative closely with student every day's life [32]. This helps student understand the physics material taught by the teacher, so that it has a positive impact on student's learning outcomes $[13,20,33]$. Learning process that is oriented on local knowledge can improve student's learning outcomes [34]. So that learning be more meaningful.

The Achievement of Character of Sanggup Bagawi Gasan Masyarakat

Sanggup Bagawi Gasan Masyarakat is a slogan from the area of Balangan Regency. Sanggup Bagawi Gasan Masyarakat stands for Sanggam which means the ability to carry out a development based on sincerity and togetherness or cooperation [35]. The achievement of character of sanggup bagawi gasan masyarakat is obtained from character's observation sheet. Aspects being observed include communication, cooperation in achieving goal, motivating others, and helping others. The result of student character's achievement of sanggup bagawi gasan masyarakat can be seen in Table 4.

Table 4. Result of the Achievement of Student's Character

\begin{tabular}{ccc}
\hline Meeting & Average & Category \\
\hline I & 3.22 & Very good \\
II & 3.18 & Good \\
III & 3.37 & Very good \\
Total number & 3.25 & Very good \\
\hline
\end{tabular}

Table 4 shows that the achievement of student's character is in the very good category. The achievement of character of sanggup bagawi gasan masyarakat is the character that is expected to emerge when the student solves a problem, in this case is when doing practicum. This is supported by Fajarini's research which states that local wisdom can function effectively in the character of education [36]. This is also in accordance with researches that state a physics module which is integrated to the local wisdom can train student's character $[5,13]$.

\section{CONCLUSION AND SUGGESTION}

The physics module that is integrated to the local wisdom to grow the character of sanggup bagawi gasan masyarakat is appropriate to be used on temperature and heat materials in high schools level. The developed module can be used as an alternative to grow students' characters. Besides that it can make learning physics fun and meaningful, because the facts that are presented are close to students' daily lives. 
The Development and Validation of a Local Wisdom-Integrated Physics Module... Misbah, Maya Hirani, Syubhan Annur, Nurul F Sulaeman, Mohd Ali Ibrahim

\section{REFERENCES}

[1] Oktaviana, D., Hartini, S., \& Misbah, M. (2017). Pengembangan Modul Fisika Berintegrasi Kearifan Lokal Membuat Minyak Lala Untuk Melatih Karakter Sanggam. Berkala Ilmiah Pendidikan Fisika, 5(3): 272-285.

[2] Kamaruddin, S. A. (2012). Character education and students social behavior. Journal of Education and Learning, 6(4): 223-230.

[3] Martawijaya, M. A. (2015). Buku fisika peserta didik berbasis kearifan lokal untuk meningkatkan karakter dan ketuntasan belajar. Jurnal Sains dan Pendidikan Fisika, 10(3).

[4] Wibowo, A., \& Gunawan. (2015). Pendidikan karakter berbasis kearifan lokal di sekolah: konsep, strategi, dan implementasi. Pustaka Pelajar.

[5] Hartini, S., Isnanda, M. F., Wati, M., Misbah, M., An'nur, S., \& Mahtari, S. (2018, September). Developing a physics module based on the local wisdom of Hulu Sungai Tengah regency to train the murakata character. In Journal of Physics: Conference Series (Vol. 1088, No. 1, p. 012045). IOP Publishing.

[6] Mastuang, M., Misbah, M., Yahya, A., \& Mahtari, S. (2019, February). Developing The Physics Module Containing Quranic Verses To Train The Local Wisdom Character. In Journal of Physics: Conference Series (Vol. 1171, No. 1, p. 012018). IOP Publishing.

[7] Kartimi, K. (2014). Implementation of Biology Learning Based On Local Science Culture to Improvement of Senior High School Students Learning Outcome In Cirebon District and Kuningan District. Scientiae Educatia: Jurnal Pendidikan Sains, 3(2): 1-10.

[8] Arfianawati, S., Sudarmin, M., \& Sumarni, W. (2016). Model Pembelajaran kimia berbasis etnosains untuk meningkatkan kemampuan berpikir kritis siswa. Jurnal Pengajaran MIPA, 21(1): 46-51.

[9] Pornpimon, C., Wallapha, A., \& Prayuth, C. (2014). Strategy challenges the local wisdom applications sustainability in schools. Procedia-Social and Behavioral Sciences, 112: 626-634.

[10] Ratana-Ubol, A. (2016). Enhancing local wisdom through lifelong learning in Thailand. Culture. Biography \& Life-long learning, 2(2): 57-68.

[11] Supriyadi, Haeruddin, \& Nurjannah. (2016). Peningkatan kemampuan memecahkan masalah antara model penalaran kausal berbasis etnosains dan sains modern. JRKPF, 3(2): 35-39.

[12] Hartini, S., Misbah, M., \& Resy, R. (2017). Pengembangan modul fisika berintegrasi kearifan lokal hulu sungai selatan. Jurnal Inovasi Dan Pembelajaran Fisika, 4(2): 157-162.

[13] Hartini, S., Misbah, Helda, \& Dewantara, D. (2017, August). The effectiveness of physics learning material based on South Kalimantan local wisdom. In AIP Conference Proceedings (Vol. 1868, No. 1, p. 070006). AIP Publishing.

[14] Khusniati, M. (2014). Model pembelajaran sains berbasis kearifan lokal dalam menumbuhkan karakter konservasi. Indonesian Journal of Conservation, 3(1).

[15] Aisyah, A. R. (2014). The Implementation of Character Education Through Contextual Teaching and Learning at Personality Development Unit in The Sriwijaya University Palembang. International Journal of Education and Research, 2(10): 203-214.

[16] Abu, L., Mockhtar, M., Hassan, Z., \& Suhan, S. Z. D. (2015). How to develop character education of madrassa students in Indonesia. Universitas Ahmad Dahlan.

[17] Rahyono, F. X. (2015). Kearifan Budaya Dalam Kata Edisi Revisi. Jakarta: Wedatama Widya Sastra.

[18] Satriawan, M., \& Rosmiati, R. (2017). Pengembangan bahan ajar fisika berbasis kontekstual dengan mengintegrasikan kearifan lokal untuk meningkatkan pemahaman konsep fisika pada mahasiswa. JPPS (Jurnal Penelitian Pendidikan Sains), 6(1): 1212-1217.

[19] Mannan, M. N. (2015). Pengembangan perangkat pembelajaran berbasis kearifan lokal untuk mengembangkan karakter positif siswa sd. Jurnal Inovasi dan Pembelajaran Fisika, 2(2): 141-146.

[20] Hartini, S., Firdausi, S., Misbah, M., \& Sulaeman, N. F. (2018). The Development of Physics Teaching Materials Based on Local Wisdom to Train Saraba Kawa Character. Jurnal Pendidikan IPA Indonesia, 7(2): 130-137.

[21] Wahyuni, S. (2015). Developing Science Learning Instruments Based on Local Wisdom to Improve Student's Critical Thinking Skills. Indonesian Journal of Physics Education, 11(2): 156-161. 
JIPF, Vol. 5 No. 1, January 2020

[22] Pamungkas, A., Subali, B., \& Linuwih, S. (2017). Implementasi model pembelajaran IPA berbasis kearifan lokal untuk meningkatkan kreativitas dan hasil belajar siswa. Jurnal Inovasi Pendidikan IPA, 3(2): 118-127.

[23] Widoyoko, E. P. (2016). Evaluasi program pembelajaran. Yogyakarta: Pustaka Pelajar.

[24] Hake, R. R. (1998). Interactive-engagement versus traditional methods: A six-thousand-student survey of mechanics test data for introductory physics courses. American journal of Physics, 66(1): 64-74.

[25] Suryani, D. I., Suhery, T., \& Ibrahim, A. R. (2014). Pengembangan Modul Kimia Reaksi Reduksi Oksidasi Kelas X SMA. Jurnal Penelitian Pendidikan Kimia: Kajian Hasil Penelitian Pendidikan Kimia, 1(1): 18-28.

[26] Rizta, A., Siroj, R. A., \& Novaliana, R. (2016). Pengembangan Modul Materi Lingkaran Berbasis Discovery untuk Siswa SMP. Jurnal Elemen, 2(1): 72-82.

[27] Zulhaini, Z., Halim, A., \& Mursal, M. (2016). Pengembangan Modul Fisika Kontekstual Hukum Newton Untuk Meningkatkan Pemahaman Konsep Fisika Siswa Di Man Model Banda Aceh. Jurnal Pendidikan Sains Indonesia, 4(1).

[28] Prastowo, A. (2015). Panduan kreatif membuat bahan ajar inovatif. Jogjakarta: DIVA pres.

[29] Rajabi, M., Ekohariadi, E., \& Buditjahjanto, I. G. P. (2015). Pengembangan Perangkat Pembelajaran Instalasi Sistem Operasi Dengan model Pembelajaran Berbasis Proyek. Pendidikan Vokasi: Teori dan Praktik, 3(01).

[30] Wahyuningtyas, D. T., \& Shinta, R. N. (2017). Penggunaan Modul Pembelajaran Penjumlahan Dan Pengurangan Bilangan Bulat Dengan Pendekatan CTL (Contextual Teaching And Learning) Untuk Meningkatkan Pemahaman Konsep Siswa Kelas IV Sekolah Dasar. Jurnal Pendidikan (Teori dan Praktik), 2(1): 12-20.

[31] Darmiatun, S. (2013). Menyusun Modul Bahan Ajar Untuk Persiapan Guru Dalam Mengajar. Yogyakarta: Gava Media.

[32] Asfiah, N., Mosik, M., \& Purwantoyo, E. (2013). Pengembangan Modul IPA Terpadu Kontekstual Pada Tema Bunyi. Unnes Science Education Journal, 2(1).

[33] Hidayanto, F. (2016). Pengembangan Modul Fisika SMA Berbasis Kearifan Lokal Untuk Mengoptimalkan Karakter Peserta Didik (Doctoral dissertation, Fisika/FKIP).

[34] Azizahwati, Z. M., \& Yassin, R. (2015). Pengembangan Modul Pembelajaran Fisika SMA berbasis Kearifan Lokal Untuk Meningkatkan Hasil Belajar Peserta didik. Prosiding Pertemuan Ilmiah XXIX HFI Jateng \& DIY, Yogyakarta, 70-73.

[35] Hidayat, K. (2007). SANGGAM Perjalanan Panjang Menuju Otonomi Balangan 1963 - 2003. Kab. Balangan: Perum Percetakan Negara RI Cabang Surabaya dan Pemrakarsa.

[36] Fajarini, U. (2014). Peranan kearifan lokal dalam pendidikan karakter. SOSIO-DIDAKTIKA: Social Science Education Journal, 1(2): 123-130. 